Marquette University

e-Publications@Marquette

College of Education Faculty Research and

Publications

Education, College of

6-1-2018

Making the Invisible Visible: Inviting Persons with Disabilities into the Life of the Church

Mary E. Carlson

Marquette University, mary.carlson@marquette.edu

Accepted version. Horizons, Vol. 45, No. 1 (June 2018): 46-73. DOI. (C) 2018 College Theology Society. Used with permission. 
Marquette University

\section{e-Publications@Marquette}

\section{Education Faculty Research and Publications/College of Education}

This paper is NOT THE PUBLISHED VERSION; but the author's final, peer-reviewed manuscript.

The published version may be accessed by following the link in the citation below.

Horizons, Vol. 45, No. 1 (June, 2018): 46-73. DOI. This article is (C) Cambridge University Press and permission has been granted for this version to appear in e-Publications@Marquette. Cambridge University Press does not grant permission for this article to be further copied/distributed or hosted elsewhere without the express permission from Cambridge University Press.

\section{Contents}

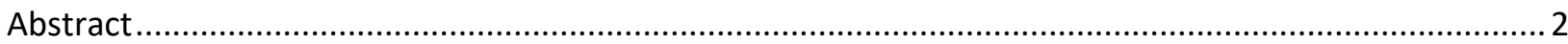

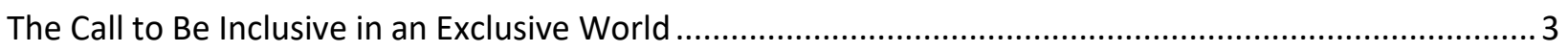

Disability Liberation Theology and the Model of Marginalized or Minority Groups ................................ 5

Christian Anthropology and the Question of What Makes Us Human............................................. 8

Making All Visible through Sharing Lived Experience and the Celebration of the Eucharist ................... 10

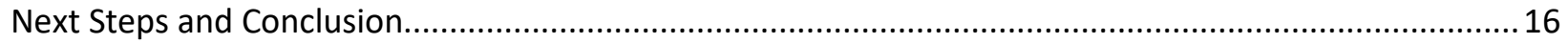

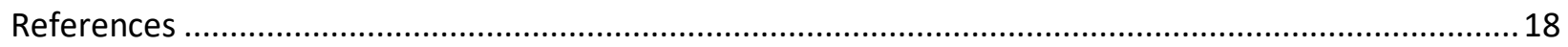

\section{Making the Invisible Visible: Inviting Persons with Disabilities into the Life of the Church}




\title{
Mary Carlson
}

\author{
Marquette University, Milwaukee, WI
}

\section{Abstract}

Christianity espouses the dignity of all humanity and professes welcome for all to the communion of saints. Yet people with disabilities, especially those with more severe or profound physical or psychological disabilities, are largely invisible inside our houses of worship. This article examines the meaning of dignity and inclusion through the lenses of Christian anthropology, disabilities liberation theology, and the lived experience of persons with disabilities. It concludes with some suggestions on how to begin inclusion.

What does it mean to be made in the image and likeness of God when an individual's body does not cooperate in leading a "normal" life, or when one's mind may be in communion with other minds only on serendipitous occasions? What does it mean to be an embodied soul, when the body and mind that are enmeshed with the soul do not conform to societal norms of wholeness, or saneness, or beauty, or ability? Most importantly with regard to church practice, what does it mean, at the banquet of the Eucharist, the outward symbol of inclusion in the Body of Christ, if disabled persons are disallowed, uninvited, or ignored and are, therefore, invisible? A number of theologians have stressed that inclusion in the life of the church means much more than physical accessibility for persons with disabilities-it means engendering in them a sense of belonging. "To be included, you just need to be present. To belong, you need to be missed." 1 But, in order to be missed, someone must be aware of your existence. Theologian Dawn DeVries explains the problem in this way:

What cannot be seen is not real, and thus cannot be a problem.... Unfortunately for the citizens ... who have disabilities, however, the lack of accessible public space has rendered them invisible to many of their neighbors; and this invisibility has, in turn, functioned precisely to convince those neighbors that they do not exist. $\stackrel{2}{2}$

In fact, persons with disabilities are often so invisible in churches that if, as in Matthew 25:37-39, one asked, "When did I see you, Lord?" the answer would not likely be that it was in church. ${ }^{3}$ Ralph Ellison describes such disappearance from the public consciousness in Invisible Man, his heartbreaking novel of the personal and societal degradation brought about by racism and marginalization:

I am an invisible man. . . I I am a man of substance, of flesh and bone, fiber and liquids - and I might even be said to possess a mind. I am invisible, understand, simply because people refuse to see me. Like the bodiless heads you see sometimes in circus sideshows, it is as though I have been surrounded by mirrors of hard, distorting glass. When they approach me they see only my surroundings, themselves or figments of their imagination, indeed, everything and anything except me..$^{4}$

The church's failure to recognize persons with disabilities as full members of the church has rendered them as invisible as Ralph Ellison's "invisible man." Ellison's novel tells the story of a bright young African American man who starts college full of promise. While the story is fictional, it is instructive because it 
faithfully portrays the social isolation felt by many people with disabilities. Due to nightmarish circumstances beyond his control (including physical and mental abuse, condoned by a racist, classist society) he suffers what we would now call post-traumatic stress disorder. His subsequent mental illness, and society's inability to take notice of him truly and recognize his needs, lead him to homelessness, despair, and "invisibility." Unlike the society around him, though, the man (who is so invisible he does not even have a name) never loses his ability to see that society is better off with all kinds of people including people like him, than without:

Whence all this passion towards conformity anyway? Diversity is the word. Let man keep his many parts and you will have no tyrant states. Why, if they follow this conformity business, they'll end up by forcing me, an invisible man, to become white, which is not a color but the lack of one. Must I strive towards colorlessness? But seriously and without snobbery, think of what the world would lose if that should happen. America is woven of many strands. I would recognize them and let it so remain. $\underline{5}$

This article will describe the problem and explore the meaning of exclusion through the lens of disability liberation theology, which views theology from the margins, from the viewpoint of persons with disabilities, and which privileges lived experience. It embraces the conviction from Christian anthropology that all persons are made in the imago Dei, and therefore have a birthright to full inclusion in church and society. This view honors Ellison's sentiment that we are better with all kinds of people. While many theologians prefer to use a Christian anthropology approach, focusing on individuals, rather than using a disability liberation theology approach, which focuses on marginalized groups, I find both useful. The purpose here is to influence church dialogue and practice to be more inclusive, and to make the church more reflective of the kingdom of heaven. While I will discuss the failure of segments of the church to see all persons with disabilities as fully human beings (which renders them virtually invisible), I will emphasize a small group of people who have severe and multiple disabilities. This article will focus on inclusion in all facets of church life, but especially in the liturgy of the Eucharist. It will end with pragmatic suggestions.

\section{The Call to Be Inclusive in an Exclusive World}

Although I write from a Catholic Christian perspective, the call for houses of worship to be made accessible for all has a basis in many Sacred Scriptures, including the Quran, the Torah, and the New Testament. Aside from scriptural admonitions, representatives of major world religions and the various branches within those religions have called for more accessibility and more meaningful inclusion of persons with disabilities. In a 1995 report, UNESCO called for all world religions not only to be more physically inclusive, but also to open clerical roles to people with disabilities. At that time, UNESCO noted, "Many religious orders do not allow disabled people to become priests or leaders," and that is still true in many cases. $\underline{6}$

Exclusion is not a new phenomenon, nor is the admonition against it. "You shall not revile the deaf or put a stumbling block before the blind," says the Lord God in the book of Leviticus. ${ }^{?}$ Unfortunately, even as the United States' Americans with Disabilities Act (ADA) was being passed in 1990, promising more accessibility to persons with disabilities, a number of religious organizations, including Catholic churches, fought jurisdiction over their buildings. Citing financial hardship and separation of church and state, they were successful in avoiding mandated changes. ${ }^{-}$Mary Jane Owen, executive director of the National 
Catholic Partnership on Persons with Disabilities (NCPD), said at the time, "If bars are more accessible than altars, or theaters more welcoming than Churches, more is the shame for us."

In Christianity, Jesus' call for respect and inclusion of all persons is clear from the gospels. While the call may be clear, it has been largely unheeded, so it must be restated. The focus of this article is that all of God's beloved, perhaps especially the ones whom Jesus healed and comforted, must be included in the life of the Church. As evidence of that call, in the Gospel of Matthew alone, there are at least seventeen mentions of healings of various diseases or disabilities of body or mind. $\underline{10}$

How does the church interpret the meaning of those healings, and what message should they have for us today? One powerful interpretation came from the United States Conference of Catholic Bishops (USCCB), which issued the Pastoral Statement of U.S. Catholic Bishops on Handicapped People in 1978, addressing the dignity, needs, and rights of persons with disabilities. The teaching was reaffirmed in 1988 and published as the Pastoral Statement of U.S. Catholic Bishops on Persons with Disabilities. The language in the original version, while sensitive at the time, was changed from "handicapped" to "with disabilities" in 1988 to reflect the more current preference in the community of persons with

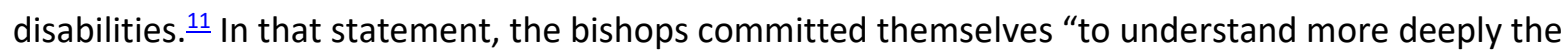
pain and the potential of our neighbors who are blind, deaf, mentally disabled, emotionally impaired; who have special learning problems; or who suffer from single or multiple disabilities." $\underline{12}$

The statement called for fuller integration of the disabled in the church and society so that we may "discover the Kingdom of God in our midst" and seeks an end to the sinfulness of prejudice and discrimination, both institutional and individual. Perhaps more surprisingly, it was also an apology: "We have, at times, responded to the needs of our disabled people only after circumstances of public opinion

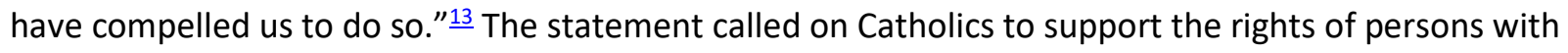
disabilities, including "rights that enable the disabled individual to achieve the fullest measure of personal development of which he or she is capable." $\underline{14}$ It called on the faithful to work actively for justice for the disabled, and, "moreover, individuals and organizations at every level within the Church should minister to persons with disabilities by serving their personal and social needs." $\stackrel{15}{\text { It recognized }}$ persons with disabilities as a marginalized group, before use of the term marginalized was widespread, and as the kind of people whose company Jesus sought. "The Church finds its true identity when it fully integrates itself with these 'marginal' people, including those who suffer from physical and psychological disabilities." $\underline{16}$ The statement continued by clearly stating that "mere cost must never be the exclusive consideration" in providing accessibility. $\underline{\underline{17}}$

Partially heeding that teaching, parishes have made some progress. According to a recent study, 96 percent of Catholic parishes have a wheelchair-accessible entrance, and 93 percent "offer accommodations to allow those with disabilities to participate in parish social events." 18 However, that same survey states that only 51 percent of parishes have a sanctuary that is accessible, which limits ministry roles. Additionally, only roughly half of parishes "always" offer accommodations for a wide variety of persons with disabilities (including physical, sensory, and intellectual) in terms of youth and adult faith formation, and only 30 percent of parishes have a staff member responsible for serving people with disabilities. So, despite clear teaching, problems of exclusion persist in many parishes, even those that have made some accommodations. There has been a delayed recognition that many Catholics will become disabled as a result of aging, and will need the very accommodations that should already have been in place for people who currently have disabilities. "While it can be easy to see the 
need for physical renovations, such as a ramp or an elevator to allow people to enter a church building, it's up to the parish to decide whether it is necessary to, for example, lower a holy water font or to purchase a $\$ 1,200$ sound system for the hearing impaired." $\underline{19}$

Some aspects of worship may be almost universally available while others are not. For instance, activist Jane Bittle, who is blind, is a leader in her congregation, and is able to participate in many aspects of church life. However, she notes: "I've always had the attitude that if I want to do something, I just go and do it. But I don't go to Stations of the Cross because the services are not in Braille. If I can't fully participate, I don't go. Our church isn't there yet." The discouragement Bittle feels from physical exclusion is experienced by many Catholics who face inaccessible churches. According to the National Organization on Disabilities, while 85 percent of people with disabilities say religious faith is important in their lives, compared to people without disabilities they are 7 percent less likely to attend church at least once per month. They are 10 percent more likely never to attend church at all. $\underline{\underline{2}}$

Although the problem of exclusion is difficult to quantify (since it is challenging to count someone who isn't there), it can still be addressed through the social justice teachings, such as those above, and through disability liberation theology and Christian anthropology, described below.

\section{Disability Liberation Theology and the Model of Marginalized or Minority Groups}

Like other stigmatized groups before them, persons with disabilities have used liberation theology to examine church history and praxis from the "underside" or "backside" as Gustavo Gutiérrez, one of liberation theology's founders, puts it. If looked at from the margins,

theological reflection would then necessarily be a criticism of society and the Church insofar as they are called and addressed to the word of God; it would be a critical theory, worked out in the light of the Word accepted in faith and inspired by a practical purpose. . . Theology as critical reflection thus fulfills a liberating function for humankind and the Christian community from fetishism and idolatry. $\underline{21}$

Gutiérrez moved from theory to praxis in outlining the various aspects of liberation, or the struggle for a new creation. He yoked liberation to salvation and to the ways that aspects of liberation reflect the role of the church as sacrament. The church's role is sacramental both in the usual sense of our full communion with one another-in, as, and of the Body of Christ in the Eucharist-and as an eschatological promise of the already-but-not-yet kingdom of heaven. When Jesus announced, "The time has come; the Kingdom of God is upon you" (Mark 1:15), he was declaring the beginning of the end of the exploitation that prevented marginalized peoples from being considered fully human. Jesus pronounced that "a Kingdom of justice which goes even beyond what they could have hoped for has begun. ... They are blessed because the Messiah will open the eyes of the blind and give bread to the hungry."를

The focus of all liberation theologies is not only eternal salvation of souls, but the possibility for sociopolitical justice for marginalized, embodied souls while they are on earth. These theologies have many forms (feminist, womanist, mujerista, black, South and Central American, Asian, and disability, for example) that stress human dignity, enshrined by our being made in the imago Dei and by the Incarnation of Jesus. In each theology, we are called to live out the Beatitudes. 
One of those theologies, disability liberation theology, has made the church more aware of people formerly hidden in shadows. People with disabilities (or as some self-advocates prefer to be called, differently abled, or persons with impairments) are still marginalized in churches and in society, but there is a growing call for full inclusion. $\underline{23}$ No matter where our bodies fall on the abled-disabled continuum, "the sacramentality of the Catholic Christian tradition is based in the incarnation, which means that the materiality of human beings and of our world has an intrinsic sacredness." $\underline{24}$ The late Nancy Eiesland, one of the main proponents of that theology, in her book The Disabled God: Toward a Liberatory Theology of Disability, describes the disability rights movement, and proposes that Christianity accept a liberationist theology in which people with disabilities identify with Jesus' broken body before and during his crucifixion. She challenges the Christian Church, then, to treat persons with disabilities as what they are, the Body of Christ: "People with disabilities will accept no less than the church's acknowledgement of us as historical actors and theological subjects and its active engagement in eliminating stigmatizing social practice and theological orientations from its midst." $\underline{25}$

Eiesland and many others in the disability rights movement and disability liberation theology view people with disabilities as a minority group: $\underline{\underline{26}}$

The minority group paradigm relies on the definition of a minority group as a "group of people who, because of their physical or cultural characteristics, are singled out from others in the society in which they live for differential and unequal treatment, and who therefore regard themselves as objects of collective discrimination." $\underline{27}$

Using the minority group model, people with disabilities were able to achieve civil rights protections under the law. However, just as happened with other minority groups, American society has sometimes led, as the church followed, slowly, in allowing fuller membership. As with other liberation theologies, the viewpoint here is not from the mainstream, but from the margins. Eiesland's book, and her later work (including the book she edited with Don E. Saliers), were ground-breaking in calling churches to task for their exclusion. $\underline{28}$ This exclusion may occur through sins of omission, such as not making buildings accessible, or commission, such as excluding those with disabilities from leadership (especially clerical) roles. $\underline{29}$ In the Catholic Church, only 17 percent of parishes surveyed reported having a person with disabilities on staff (including priests), and it is unclear whether the person had the disability before being hired or acquired the disability after. $\frac{30}{}$ Saliers addresses exclusionary practices not only in society, but in our liturgies:

Against the oppressive iconography and the mythology of the perfect body something needs to be revealed of another way of doing, and another way of being. ... Persons with disabilities comprise an increasingly active and critically reflective body of participants in Christian communities of worship. Moreover, the spiritual pulse and the gifts such persons bring to churches and synagogues-a way of seeing things long obscured and neglected-raise important theological and spiritual questions about the nature and quality of our worshipping assemblies. $\frac{31}{3}$

Like other minority groups throughout history, people with disabilities have been excluded and had their existence hidden or erased for reasons both conscious and unconscious, which may be associated with the stigma often attached to disabilities. Although it is not the aim of this article to explore stigma or stigmatization, it is important to understand the role of stigma as a background to able-ism (or, as Dawn DeVries calls it, handicappism), the prejudice and discrimination directed toward persons with 
disabilities. $\frac{32}{2}$ Theologian Sarah Melcher discusses the role stigma plays in exclusion from both participating in and officiating at liturgies. Using Erving Goffman's theory, she writes:

Goffman is the first to define stigma as a socially constructed phenomenon that deeply discredits a human being on the basis of physical attribute, character, or "tribal" affiliation (race, nation or religion). When a community has constructed a stigma, it has made legitimate a particular kind of response to difference, a response that classifies the person with a stigma as failing to meet community standards of normalcy.... The stigmatization process tends to assign other socially devalued characteristics to the person with stigma. Finally, stigma is usually accompanied by some form of ostracism, either limiting social interaction for the stigmatized or excluding them from the community altogether.... In this way, whose "usualness" is confirmed when another's access to community or altar is restricted? $\underline{33}$

DeVries writes that Christians may be only subliminally aware that the doctrine of creation is often used by Christians to "assert the notion of an originally 'perfect' and 'normal' world, beside which all impairment and disease are seen as evil deviations - the result of $\sin$," which leads to stigmatization..$\underline{34}$ Devries observes further that

a final structure of belief that supports handicappism is stigmatization. ... The person is not seen-only the disability counts. And the disability is taken to be very disabling. The more malevolent form of stigmatization is seen in the blaming of persons with disabilities for their own and society's ills, and the avoidance of those persons as if their disabilities were contagious. $\frac{35}{}$

Another branch of liberation theology, womanist theology, fights stigma associated with bodies, especially the bodies of black women. M. Shawn Copeland's womanist theological anthropology, Enfleshing Freedom: Body, Race, and Being, is an exercise in concretizing the sacramentality of the body, and offers a theology of "re-membering and remembrance," with a strong emphasis on the Eucharist. $\frac{36}{3}$ The book begins with five major convictions, which support the dignity of the human body (in all its forms) through its relationship with the Trinity. Those convictions are

that the body is a site and mediation of divine revelation; that the body shapes human existence as relational and social; that the creativity of the Triune God is manifested in differences of gender, race and sexuality; that solidarity is a set of body practices; and that the Eucharist transforms our bodies as the body of Christ. .37

I borrow from Copeland because she writes so powerfully regarding both the exclusion of people because their bodies are recognized as belonging to a particular minority group, and the anthropology of the individual body as sacred because of its membership in the Body of Christ. This viewpoint accommodates factions that are sometimes at odds with one another: disability liberation theologians, who are often disabled and able to express and call attention to themselves and to their rightful place in the church; and more severely disabled people, who cannot readily express themselves, who depend upon others to recognize from a Christian anthropological viewpoint that radical solidarity is a necessary practice in functioning as the Body of Christ.

While Copeland writes from the marginalized community of black women, her convictions can be applied to other marginalized communities, such as people with disabilities. It would be wrong to 
conflate these communities, as no two individuals, and no two groups, have identical struggles, schemas, or experiences - which is one reason why liberation theologies place such value on the hermeneutic of lived experience. $\frac{38}{H}$ However, one marginalized group can look to another and be both informed and inspired by the fight to be recognized as full members of the church. For instance, in asking the question, "What would Catholic theological ethics look like if it took the 'Black Experience' seriously as a dialogue partner?" moral theologian Bryan Massingale notes that

to raise the question ... is to signal the reality of absence, erasure, and "missing" voices. The question is necessary only because the "Black Experience" ... and the bodies who are the subjects of this experience have been all too often rendered invisible and therefore "missing" in U.S. Catholic ethical reflection. $\frac{39}{}$

We might pose the same question, substituting "disabled" for "Black": What would theological ethics (and ethical church practice) look like if the church took the "disabled" experience seriously? The church's failure to take the disabled experience seriously, the failure to throw light on the wider community of people with differing abilites, leads to a type of invisibility that, for some, like Ellison's "invisible man," is like unto death: "Light confirms my reality; gives birth to my form . . . without light, I am not only invisible, but formless as well; and to be unaware of one's form is to live a death." $\underline{40}$

\section{Christian Anthropology and the Question of What Makes Us Human}

Now to address the questions posed at the beginning of this article: What does it mean to be made in the image and likeness of God when a body does not cooperate in leading a "normal" life, or a mind may be in communion with other minds only on serendipitous occasions? What does it mean to be an embodied soul, when the body and mind that are enmeshed with the soul do not conform to societal norms of wholeness, or saneness, or beauty, or ability? Most importantly with regard to church practice, what does it mean at the banquet of the Eucharist for persons with disabilities to be disallowed, uninvited, or not included?

Copeland's viewpoint of the person as defined by our relationship with the divine and in solidarity with one another (rather than emphasizing the individual) strengthens the connection between this anthropological viewpoint and her work as a womanist liberation theologian. In framing this anthropological view, I also borrow from Susan Ross, who writes, "A Christian theological anthropology has Christ at its center-a Christ who desires to be with his friends, a God who desires that there be a world in which God's glory can be revealed." ${ }^{41}$ She searches for what it means to be a human through the lens of desire: both God's desiring of humanity and our desire for God. This viewpoint will be especially important when considering the uniqueness of those individuals with severe or profound intellectual and/or physical disabilities. It is important because it is Christological-the Incarnation will be a central consideration in human dignity and belonging, as will the Eucharist-and it places the emphasis on God's desire for us, regardless of our gifts and strengths, or perceived lack of each.

Many times, the questions of Christian anthropology are focused on what makes humans unique among creation. Those avenues of exploration have often focused on capacity or agency: Are humans unique due to reason? Language? Free will? Our desire, or longing? Our ability to distinguish ourselves from others as a "self?" This article, like the work of Hans Reinders and others, refocuses the quest by turning to a small subset of people, those who, to our best knowledge, do not demonstrate sound reasoning, understandable language, a sense of self, or perhaps even free will. $\underline{42}$ This is not to say that persons with 
profound disabilities do not have those capacities; it is only to say that they may have little or no ability to act with agency in demonstrating those capacities.

Reinders says that his book Receiving the Gift of Friendship "makes an unusual claim about unusual people: it says that people with profound intellectual disabilities are people just like other people... and ... that the best way to understand human beings is not found in the human faculties." $\underline{\text { uㅡ }}$ Reinders' theory is that we are not unique in God's creation because of our capacities, or our desires, but rather our uniqueness lies in God's desire for relationality with us. Reinders, who has devoted most of his career to the theology of persons with disabilities, says what is needed to live a fully human life is belonging. His main arguments are that people with profound disabilities are people just like us, and that we are all defined as dignified human beings, not by what we can do, but by our congenital relationship with God. It comes to this:

"Choice" in itself ... presupposes that the good life for human beings is coextensive with a chosen life. What follows is that "goodness" and "meaning" is conferred on people's lives by virtue of their own authorization. ... It will be clear that this conception of the good life excludes all those incapable of purposive agency ... who . . . cannot affirm their own being. .44

So humanity as a whole may be defined through our relationship with God, who became one with us, and one another. In broadening our thinking regarding what makes us human, we recognize that family, sexuality, religion, ethnicity, and even elements that were once thought to be categorical (such as race, gender identity, or nationality) are multifaceted. The same is true of able-bodied-ness and intelligence. About individual identity, Ross writes: "Individual human identities are multiple and in flux. . . We are enmeshed in different communities, relationships, identities. So, our definition of what it means to be a self, a person, is no longer a seamless, essential self, if it ever was. We are all defined in ways that point to our own histories." $\underline{45}$

With this understanding of human identity as inherently dignified, despite differences, church practices of inclusion or noninclusion may be examined. In order to carry out that examination, a critical-historical lens and other methodologies inspired, in part by Vatican II, will be used, including disability liberation theology.

Reinders looks at ways that human beings with profound disabilities are served-or not-by the disability rights movement. $\frac{46}{H e}$ critiques the benefit to profoundly disabled people, in that the focus of disability rights is to allow people to participate in activities they choose that are open to the partially or fully abled. This view presupposes intellectual agency in making one's choices known. I think his critique misses the mark a bit, since disability rights is a sociopolitical movement that does not purport to be a theology. For instance, other sociopolitical movements, such as the United States civil rights and women's movements, were influential in gaining societal recognition for marginalized groups before the corresponding liberation theologies were widespread. With a group emphasis, the rights movements would not necessarily have the same emphasis on an anthropological view of individuals. However, his criticism hits the mark squarely in that the movement tends to address the needs of people only above a certain level of demonstrable intellectual capacity, which would exclude people with profound disabilities. Reinders and Molly Haslam are among only a handful of writers who have attempted to look at Christian anthropology through a lens other than one based on self-agency or capacities. And both are correct in critiques of the limitations of the disability rights movement in that it centers on "choices." However, there has been demonstrable good accomplished, even if we look only at the most 
basic physical changes that have been made to places covered by disability law. In places that people with profound disabilities live (such as private homes, group homes, or institutions) or travel to (hospitals, clinics, or schools) there is at least the benefit of more ease of movement, and there has been much other benefit to those who have less serious disabilities. But Reinders makes a much stronger point in agreeing with Ross, Haslam, Mary Jo lozzio, that we should not assume that independence is at the top of the list of wishes and hopes for those who cannot make all of their needs known.

And, for that small group, therein lies part of the problem.

Self-advocates are the vanguard of the movement-but, of course, the limitation is in the title. Selfadvocates must have the capacity to advocate for themselves. A writer with disabilities has a natural place of privilege when writing regarding the physical, spiritual, and psycho-social needs of persons with disabilities. But since our schemas are somewhat constrained by the limits of our own experience, people whose disabilities allow them to act as their own agents cannot fully represent the viewpoint or lived experience of those with handicapping conditions so profound that they cannot make their needs known linguistically. None of us truly can-but we can try.

\section{Making All Visible through Sharing Lived Experience and the Celebration of the Eucharist}

The church reduces persons with disabilities to the invisibility experienced by Ellison's nameless title character when it fails to invite and welcome them fully into the many dimensions of its corporate life. Reinders echoes the man's need for all kinds of people, and believes that

what ultimately prevents people with intellectual disabilities from full participation in our society is the fact that they are generally not seen as people we want to be present in our lives. We don't need them. Not being wanted by significant others, as every psychologist can tell, is the cause of serious personality disorders in many people. $\stackrel{49}{\underline{9}}$

And since relationship is primary to life, Reinders says that we can presume, even for those who cannot make their needs known, that being chosen as a friend is the greatest good we can do for them, and for the common good: "The ultimate good is not necessarily coextensive with what all people desire, but with what is desirable for all people because of the human beings they are. Therefore, the human good must be what all people can participate in. Friendship is that kind of good." "Desiring is something that has physical and spiritual dimensions. It is necessary to our existence, since if we do not desire to eat, or to be in relationship, we will die. But, desire can also lead to despair and death. Desire is both biological and spiritual." $\underline{51}$

We know from studies done at orphanages in the twentieth century that some babies, even though they are fed and changed, will die from a lack of love. $\underline{52}$ Just as a physical life may be extinguished, one's spiritual life may die from a lack of perceived love and nurturance. I am not certain that friendship is the greatest good we can do, but one would have to be quite hard-hearted not to see it as one great good. And Reinders' conception of friendship extends to inviting and making accommodations for all kinds of worshipers, worshipers whom we may assume have the human desire to belong. His call for friendship is nothing short of a call to obey the great commandment to love our neighbor as ourselves-and to look for neighbors whom we may have missed, so that we may love them too. 
There are, however, some problems with understanding and carrying out the friendship premise. What does it mean to be a friend to someone who is profoundly disabled? How can we, using Copeland's convictions, demonstrate solidarity as a set of body practices? In the United States, it is estimated that 1 to 3 percent of the population is in the category of profoundly disabled..$\underline{53}$ So, the first challenge to Reinders' theory is, logistically, that many of us will never personally know an individual with severe and/or multiply handicapping conditions. So, are we then free from responsibility?

Saliers would say we are not then freed, and he insists on creating a sense of belonging for all kinds of worshipers, noting the absence of those with profound disabilities. Wondering how our liturgies and language can be more inclusive, he examines three meanings of liturgy. He returns to the Latin term, leitourgia, and explains that its root meaning has to do with the work of the gathered assembly:

With its memory and hope, with its singing and praying, with eating and drinking together, with blessing one another, with anointing one another and being anointed. At root, liturgy is that common work in which the community assembles about the book of memory and hope, the font of the water of life, and the table of the word and the meal. $\underline{54}$

A second meaning of liturgy has to do with glorifying God and sanctifying what is human. "Worship does not make things holy by magic, but reveals and discloses what is already intrinsically holy by the grace of God in creation and redemption." $\underline{55}$ The third definition reflects the ongoing work of Jesus in the world by the community, the whole Body of Christ. So, in the liturgy,

we join a company, a long company of people who are quite other than we: Paul, Augustine, Teresa of Avila, Dame Julian of Norwich, Francis of Assisi, and all the martyrs. The liturgy of Jesus brings together the dead and the living, the enemy and the friend, the fractured and the whole ... and ... through the broken body in the conflicted world ... it invites praise, a life of blessing in the midst of the mess. Our first vocation is to be gathered and to sing, and to speak and to enact, to eat and drink together, to bathe and to be bathed, to be anointed, one way or another, in that slow inexorable dance of redeeming love, haltingly adagio or sometimes presto. ... Liturgy is about the ongoing work of Jesus in the world hidden and yet made palpable and visible, audible and kinetic by the Holy Spirit. $\frac{56}{}$

Saliers writes that when we exclude members, by not offering access, or catechesis, or welcome, then the hopes and fears, the hungers and thirsts, the laughter and laments of the Church are incomplete. For this act of inclusion to occur (which we could classify as one gesture of friendship), it would be necessary to survey parishioners to see what special needs exist. Each congregation can remodel itself, bit by bit, according to need, in order to welcome the new, the now-included parishioners. Then, if inclusion is to be more than just a catchphrase, "loving the other and oneself for the sake of God is a profound capacity that requires entering into the mystery of limit, into joy in the midst of tribulation, and into discovery of giftedness in difference." $\underline{57}$

Copeland emphasizes the power of the bodily practice of the Eucharist to embrace the tortured and marked body of Jesus, and the differently marked bodies of us all:

Our daily living out, and out of the dangerous memory of the torture, abuse, death and resurrection of Jesus constitutes us as his own body, raised up and made visible in the world. As his body we embrace with love and hope those who, in their bodies, are despised and 
marginalized, even as we embrace with love and forgiveness those whose sins spawn the conditions for the suffering and oppression of others. As his body, we pulse with new life, for Eucharist is the heart of the Christian community. We know in our bodies that eating the bread and drinking the wine involve something much deeper and far more extensive than consuming elements of a ritual meal. Eucharistic solidarity is a virtue, a practice of cognitive and bodily connectiveness oriented to meet the social consequences of Eucharist. $\underline{58}$

Jesus' marks are both real and symbolic, as Copeland tells us in Enfleshing Freedom, in which she writes about the significance of Christ's broken body in the Eucharist. Copeland categorically marks Jesus' body as a human body. ${ }^{59}$ She uses theological anthropology to show us that we are all enfleshed, as Jesus was; all gendered, sexed, sexualized, and cultured persons who are manifestations of the divine. Jesus, while enfleshed as a male, did nothing to indicate that gender, sexual orientation, or ethnic identity determined a person's worth. He loved, healed, and touched children, persons with disabilities, sinners - in fact, all those who had little acceptance in society.

Copeland then pushes the theological envelope by asking if we risk fetishizing or idolizing the body of Jesus by attaching the "marks" of maleness and heterosexuality (and, I might add, wholeness) to it. She does not deny that he was male, nor does she address his sexuality. Her point is, if we fetishize his maleness or sexuality above his more important universal marking, that of a human being, we risk his identification as savior for us all. Our "marks" are important, but the mark of Catholicism, the sign of the cross, should eclipse all other marks for us. It means that solidarity can never be severed from the cross nor from the radical love of God expressed through Jesus nor from the Resurrection. Liberation theologies, in solidarity, are turning the subject toward the "nobodies." This shift is not meant to be exclusive, but radically inclusive, including those formerly at the Euro-male-bourgeois center. Copeland says that we are not born racists, sexists, or homophobes (I would add able-ists), but are born into a world of bias, which can be overcome only through intentionality and intelligence in service to the broken body of Jesus. Joining the mystical Body of Christ gives us the vantage point of seeing God's face in the face of those who have suffered from our hatred and fear:

The flesh of his church is multi-layered. Pulling back layer after layer, we expose the suffering and groaning, outrage and hope of victims of history. In them we glimpse the flesh of Christ and we are drawn by that eros, his radiant desire for us, and we, too, seek to imitate his incarnation of love of the Other, love of others. The body of Jesus of Nazareth impels us to place the bodies of the victims of history at the center of theological anthropology, to turn to "other" subjects. $\underline{60}$

Copeland's theological anthropology makes clear why Jesus must be fully present in the Eucharist, to join his body with my body, with all bodies, broken or whole. If we cannot see and feel that union, viscerally and spiritually, then the mystical Body of Christ, our central symbol, loses the power of universal reflection of the power to heal us all, and to save us all. We need not see anything heroic in people with disabilities to see that we cannot have full communion without them and their "broken" bodies or minds to remind us that we cannot re-member the broken Body of Christ without them. $\underline{61}$

When we represent Jesus' body in a more vulnerable way, more people are able to recognize themselves in both the suffering, and therefore the eventual resurrection of Jesus. Many have written of the visceral power of the Eucharist to join us with Jesus and with one another. Dominique La Pierre reports an incongruous tale of beauty from the slums of Kolkata and its inhabitants-Hindus, Christians, and Muslims-who have leprosy. He recounts the story of Fr. Stephen Kovalski, whose "parish" is an 
area called the "City of Joy." He ministers to a group of people widely varying in their ability to care for themselves and/or to make their needs known, depending upon the severity of their leprosy. Fr. Stephen came from his native Poland with few possessions, the most prized of which was an image of Jesus' face from the Shroud of Turin. For him, that image, "with the downcast eyes and swollen cheeks, with punctured brow" was "the incarnation of all the martyrs of the slum. . . Each one of them wore that same face of Jesus Christ proclaiming to humanity from the heights of Golgotha all the pain, but also all the hope, of man rejected." $\underline{\text { 2 }}$ The Eucharist had always held great meaning for the priest, but,

today, in the midst of these suffering, despised and broken people, he sensed all that would be unique about this offering, this sharing of bread ... to draw closer still to the very poorest, the humblest, the most handicapped and rejected of this world. What an extraordinary source of happiness it is to have the power to enable God to express through the Eucharist the infinite quality of his love. $\underline{\underline{63}}$

Liberation theology gives credence to the witness of people who join with marginal persons, but gives pride of place to theologians who are part of a marginalized group. Nancy Eiesland, who self-identified as a person with disabilities, and the authors cited in this article so far, write from their own experience (as we all do) and have the capacity to make their needs known. Eiesland advocated for radical love and acceptance here on earth, as it will be in heaven. But, to hear from an advocate whose voice was not heard, or understood, for most of his first eighteen years, we can look to the Irish writer Christy Brown (1932-81). He came into the world the hard way, very nearly dying and taking his mother with him. However, they both lived to go home and join a family that had thirteen children who lived past early infancy (out of a total of twenty-two). Christy seems to have had cerebral palsy, probably caused by a lack of oxygen during childbirth. He was part of a loving family, yet apart; baptized in the church, yet isolated from the church community. In his autobiography, My Left Foot, he remembers being aware that his status as a person was doubted:

Most every doctor who examined me labeled me a very interesting but also hopeless case. Many told mother very gently that I was mentally defective and would remain so. That was a hard blow for a young mother... . They assured her that nothing could be done for me. She refused to accept this truth, the inevitable truth-as it seemed - that I was beyond cure, beyond saving, even beyond hope. She could not and would not believe I was an imbecile. ... She had nothing in the world to go by, not a scrap of evidence to support her conviction that, though my body was crippled, my mind was not. ... Finding that the doctors could not help in any way beyond telling her not to place her trust in me, or, in other words, to forget I was a human creature, rather to regard me as just something to be fed and washed and then put away again, mother decided then and there to take matters into her own hands. I was her child. No matter how dull and incapable I might grow up to be, she was determined to treat me on the same plane as the others, and not as the "queer one" in the back room who was never spoken of when there were visitors present. $\underline{64}$

With the exception of his left foot, Christy had little voluntary control of his body. He learned to scoot across the floor of the family home on his bottom, and was able to make grunts, which eventually turned into some functional words that only those in his family could understand. If our definition of what it means to be human through the lens of Christian anthropology was based upon demonstrable agency or rationality, at this point in Christy's life, he would not have met the criteria to be considered 
human. Therefore, the definition of humans as unique because of their desire for relationality with God, God's desire for us, and our relationality or solidarity with one another is more Catholic (both with a capital and a small $c$ ). Christy could not attend Mass, but rather listened on the radio, and he did not fully feel the welcome of the church until he went to Lourdes, which he described as the most beautiful moment of his life:

I saw that, far from being alone and isolated as I thought myself to be, I was merely one of a brotherhood of suffering that stretched over the whole globe. I remembered the courage and perseverance that shone in the faces of the afflicted people who came from all parts of the world to hope and pray at the feet of the Virgin in the Grotto. There I had seen the whole story of my life reflected in the eyes of those I had prayed with, those men and women who spoke different tongues and who lived according to different ideals, but who were now made all brothers and sisters, all part of one family, by right of a common heritage of pain. No one thought of anyone as a foreigner in that holy little village; all the barriers that separate single persons and whole nations from one another were broken down and burned away by the common need for understanding and communication which we all felt and which suffering alone could have inspired. $\underline{65}$

Eventually Christy became able, first through mastering writing with his left foot, then later, through therapy, to communicate his wishes and needs. He became a patient, a student, and then a helper of younger children at a special clinic. The clinic included a school-something, like Mass, in which he had never been included:

In the schoolroom, the more backward of the children, those who have never been able to attend normal schools with their sisters and brothers because of their "difference," are given an ordinary primary education. . . Thus one more gulf is bridged, one more link is forged in helping these children to establish ordinary contact, with ordinary people. $\underline{6}$

Ellison's "invisible man" also experiences, for one brief, shining moment, what it feels like to be seen and heard truly by others, to be recognized temporarily as human, and he is overwhelmed by the experience. "I feel, I feel that suddenly I have become more human. Do you understand? More human. . . . With your eyes upon me, I feel I've found my true family. I feel that here tonight . . . the new is being born, and the vital old revived. In each of you, in me, in us all." $\underline{67}$

How can we make ourselves recognize the humanity-and divinity-in everyone? How can we bring to fruition a Christian anthropology that views the person as dignified by birthright through the Incarnation, and through the belief that we are made in the image and likeness of God? Christy Brown's desire for "ordinary contact, with ordinary people" brings us back to Reinders' call for friendship as one way to carry out belief in such an anthropology. Earlier in this article, while supporting that call, there was a discussion of one challenge in befriending those with profound disabilities, that of not knowing any of those individuals personally. Also, many authors, like Reinders, focus on dissecting the story of Jesus curing the man born blind (John 9:1-41), thus exposing a second challenge: this and other

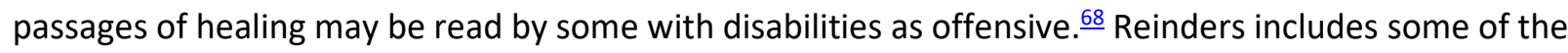
reasons for this negative reaction, such as why the man is presumed to be sinful, and why blindness is used as an insult when referring to the Pharisees. He does a creditable job of placing the disability with the Pharisees and the wisdom with the blind man. But, he comes perilously close to an older view, a view from what we might call a place of able-bodied privilege. $\underline{69}$ From that able-ist vantage point, people 
with disabilities are put on earth to show the works that God can do: such as miracle healings, kindness done toward the disabled, disabled people being here to teach the temporarily abled what really matters. While that is specifically John's point in 9:3, and real good may be done by the temporarily abled who interact with people with disabilities, there are (at least) three main problems with this line of thought.

First, blind people, in modernity, are not considered profoundly disabled, as they have many capacities and can act with agency on their own behalf. There are many degrees of blindness or low vision, and most legally blind people would probably consider themselves disabled, but not profoundly so. Second, as much as families love and cherish family members with profound disabilities, to think that God sent their family member to earth in this way for the good of others is problematic and painful. It is hard to imagine a loving God choosing to enmesh a soul with a body that is such a source of physical and/or psychological pain on purpose-even for the good of others. And, third, in his assumption that people with disabilities are sent to show God's works, Reinders seems to be disagreeing with one of his primary arguments - that people with profound handicaps do not have to do anything (the blind man makes the Pharisees look bad, and praises Jesus) to have human dignity - they just have to abide in God's friendship.

Although Reinders disagrees with aspects of liberatory disability theology, mostly on the same grounds as his arguments with the disability rights movement, he would find support in those more radical quarters. For instance, Jon Sobrino's claim that there is no salvation outside the poor argues along a similar line: if we are not poor ourselves, we must either join the poor in their struggle or actively help them to free themselves from poverty. $\underline{70}$ So, a kind of witness and solidarity is called for by Reinders that is similar to what liberation theology asks of us. The strongest section in Reinders' book is his summary of the story of L'Arche, and its founder, Jean Vanier. L'Arche is similar to Dorothy Day's radical commitment to the poor. Vanier founded the L'Arche communities for those without disabilities (called assistants) to choose to live in friendship with those with disabilities (called community members)..$\underline{1}$ There is a recognition, by the assistants, that it is only in joining with people whom society has cast as broken that we can see the brokenness in ourselves. There is a necessary focus on the group first, in the way that liberation theology calls us to task for the way we make people "other," and, once we have opened ourselves to joining the group, a focus on the imago Dei within each individual. I went through such a journey myself, spending a summer during college working with children and young adults with severe and multiple disabilities. My first day, I am ashamed to admit, I was repulsed and frightened by some of the children and youth. The unfamiliar sights, sounds, and smells blended together, masking the individuals. The presence of bodily fluids and the challenges that the children and youth had to meet each day were overwhelming to me. But, as time went on, the grace of their daily presence made me realize that I was the one who had difficulty joining their community, not the other way around. My fear of the group was replaced by an abiding sense of love and friendship for the individuals - and a recognition that they were people, just like me, and members of the Body of Christ.

The renowned theologian Henri Nouwen lived in the L'Arche community the last years of his life. At first, he resented having to take care of the most intimate needs of a young man who did not seem responsive except, at certain times, slowing procedures down by having seizures. Nouwen saw his "real work" there as being a chaplain. As time went on, however, he began to learn from the young man, Adam, how to be patient, how to appreciate different rhythms of life, and, ultimately, how to love God better. That is the ultimate act of friendship-to voluntarily spend one's life with another. Without the 
"space" that L'Arche had created, both figuratively and literally, that friendship would have been impossible. Nouwen wrote:

So we can see that creating space is not easy in our occupied and preoccupied society. And still, if we expect any salvation, redemption, healing and new life, the first thing we need is an open receptive place where something can happen to us. Hospitality, therefore, is such an important attitude. $\underline{72}$

The stories from L'Arche are profoundly moving, and filled with humility on the part of the more ablebodied assistants. Again, there is the danger of seeing people with disabilities as being there for the enlightenment of the temporarily able-bodied. But, in this case, any such notion may be set aside, as the assistants at L'Arche are choosing to live a life in community with those who would have a more difficult life without the companionship that benefits both. This is living out one of the great commandmentsloving our neighbor as we love ourselves.

\section{Next Steps and Conclusion}

We are not the Body of Christ without all of our members. My sister and brother-in-law know this, even though they have never expressed it in this way. There is a group home across the street from them, and for more than ten years they have driven one or two of the people from the group home (who were born with a genetic condition that precludes their being able to live by themselves) to church on Sunday mornings. It does not make my sister feel like a good person that she does this; rather, she often feels like a bad person, because it makes Sunday mornings crabby, hectic, and complicated rather than peaceful, as she would wish her Sundays to be. Yet she continues, because if she did not, she knows her parish would look less like the kingdom of heaven. She and her husband say that it is nothing more than loving our neighbor-even when that commandment is inconvenient.

We must ask our parish leadership, Do we know who is in our parish that doesn't come to church because of physical or psychological barriers? Is our parish church disability-accessible? Is our parish church universally welcoming? Are we working on finding our neighbors who have been invisible so that we may love and include them?

A first step might be to survey who is in our parish and ask what would make the liturgy accessible to them. A sound system? Wheelchair ramps and proper space for wheelchairs in the congregation? Largeprint hymnals? Elevators? A quiet room for people on the autism spectrum or others who need a break or want to be close but need a safe distance? A congregation does not have to start from scratch in creating a survey. There are a number of high-quality surveys in existence, such as the ones used by the Episcopal Diocese of Michigan, and the National Catholic Partnership on Disabilities, which could be modified for a particular faith community. Additionally, some faith communities, such as the United Methodists, have extensive policies and resources that could be adapted. $\underline{73}$

Some may question the presumption that people with disabilities want to attend liturgies. Most people with disabilities can make their needs known. But if a loved one is not capable of making their needs known, guardians or advocates may assume, out of a desire for solidarity, that they would like to be included in the liturgy. $\underline{\text { If }}$ If our churches are not reflective of the whole Body of Christ, we must reach out and ask parishioners if there are family members or friends who might be desirous of celebrating 
the sacraments, and make programs such as SPRED (Special Religious Development), which prepare people with special needs for sacraments and companionship, universally available. $\frac{75}{}$

Not to make accommodations so that persons with disabilities can participate in the life of the church and feel welcomed is antithetical to Sacred Scriptures, the social justice teachings of many faiths, Christian anthropology, liberation theology, and the witness of lived experience. Copeland sums up the importance of inclusion, especially in the Eucharist: "In spatial inclusion, authentic recognition and humble embrace of different bodies, Eucharistic celebration forms our social imagination, transvalues our values, and transforms the meaning of our being human, of our embodying Christ."트

Accommodation is not a favor to be done for someone we feel pity for-it is an article of faith. As God's beloved, it is right and just that persons with disabilities take their place at the Communion table. Their justice should not have to depend on our charity, but rather on our commitment to the common good and full communion. In Octogesima Adveniens Pope Paul VI decried the hypocrisy of inaction in the face of Jesus' clear teaching:

It is not enough to recall principles, state intentions, point to crying injustice and utter prophetic denunciations; these words will lack weight unless they are accompanied for each individual by a livelier awareness of personal responsibility and by effective action. . . . The Church invites all Christians to take up a double task of inspiring and innovating in order to make structures evolve so as to adapt them to the real needs of today. $\underline{\underline{7}}$

The example of L'Arche is probably as close as we can come to the eschatological reality of the kingdom of heaven here on earth. And, for most of us, it is a shining ideal to strive for but something most of us will never be able to bring ourselves to do, any more than many of us would sell our possessions and live in a Catholic Worker House in voluntary poverty. What can we do short of that? Aside from the earlier suggestions for making parishes inclusive, how can we show friendship? Aside from making our parishes inclusive, if we do not know people with profound disabilities, but a parish survey identifies people who are caregivers, giving family members a break while we spend time with the person with disabilities, allowing friendship to grow over time, would be very welcome. We can also work more actively to recognize the Body of Christ through making the environment of the church more inclusive. For instance, visual artist Janet McKenzie has done portraits of Jesus, the Holy Family, saints, and angels in new ways that help us to see ourselves, whoever we may be, in those paintings. One painting in particular drew my attention. It is the Holy Family, and the child, Jesus, appears to have a developmental delay. $\frac{78}{}$ In that image, that precious image of the child Jesus, families of persons with disabilities may see themselves as no longer invisible, but as full members of the Body of Christ. Images like that would create a wonderful sense of hospitality, and an invitation to abide in God's friendship.

We must also heed Eiesland's call for an end to restrictions on the full practice of Christianity, by incorporating practices such as universal design in buildings, and putting an end to the glass ceiling for those who are called to ministry. Jan Robitscher recalls how difficult her journey to ordination in the Episcopal Church was, because of her visual disability. In "Through Glasses Darkly: Discovering a Liturgical Place" she writes of the three dimensions of "discovering a liturgical place":

finding a physical, architectural place to worship; finding a place within the worshipping community; and finding a place in which to exercise the various charisms of liturgical 
leadership.... For too long, churches have been inaccessible to persons with disabilities, the message (whether conscious or not) being that only the unblemished may approach the altar. $\underline{79}$

Once we have helped to create the liturgical place, there is one more thing that is perhaps even more important to remember. As Copeland and Saliers would tell us, without making the "broken" or "marked" bodies visible among us, we cannot re-member Jesus' body in the Eucharist, and our closest glimpse of the kingdom of heaven becomes invisible.

\section{References}

${ }^{1}$ Swinton, John, "From Inclusion to Belonging: A Practical Theology of Community, Disability and Humanness," Journal of Religion, Disability \& Health 16, no. 2 (2012): 172-90 (emphasis in the original).

2 Devries, Dawn, "Creation, Handicappism, and the Community of Differing Abilities," in Reconstructing Christian Theology, ed. Chopp, Rebecca S. and Taylor, Mark Lewis (Minneapolis: Augsburg Fortress, 1994), 131. Devries, as an advocate, is understood here to use "seen" metaphorically.

${ }^{3}$ Dutch theologian Hans Reinders says that when he asks clergy about members of their congregation with disabilities, the most frequent response is that there are none. Reinders, Hans S., Receiving the Gift of Friendship: Profound Disability, Theological Anthropology, and Ethics (Grand Rapids, MI: Eerdmans. 2008), 335.

${ }^{4}$ Ralph Ellison, Invisible Man (1947; New York: Random House/Vintage International, 1980), 3.

${ }^{5}$ lbid., 577.

${ }^{6}$ UNESCO, "Overcoming Obstacles to the Integration of Disabled People," Report to the World Summit on Social Development, ed. Rachel Hurst (Copenhagen: Disability in Action, 1995). This denial of access to clerical roles follows in the Catholic Church's tradition of denial of ordination for marginalized groups, such as African Americans. For instance, see Davis, Cyprian, The History of Black Catholics in the United States (New York: Crossroad, 1992) and Copeland, M. Shawn, Uncommon Faithfulness: The Black Catholic Experience (Maryknoll, NY: Orbis Books, 2009). The exclusion of people with disabilities is evident from the Vision Vocation Network website (https://www.vocationnetwork.org/en/articles/show/235), which helps seekers to find the minority of orders who will take candidates with disabilities. The web page features the Benedictine Sisters of Jesus Crucified: "Founded in France in 1930, the Roman Catholic Order of Benedictines of Jesus Crucified is one of the few religious orders that widely accepts women with physical disabilities. The order maintains . . . a fully accessible facility that is currently home to 21 sisters. Sister Mary Zita, OSB, vocation director, says the community is able to accept women who are blind, have heart conditions, diabetes, orthopedic conditions, post-polio conditions, and spinal bifida. They do not accept women with mental or neurological disorders."

${ }^{7}$ Lev 19:14 (NRSV).

${ }^{8}$ Eiesland, Nancy L., "Barriers and Bridges," in Human Disability and the Service of God: Reassessing Religious Practices, ed. Eiesland, Nancy L. and Saliers, Don E. (Nashville: Abingdon Press, 1998), 200-229. 
${ }^{9}$ Helen Betenbaugh and Marjory Proctor-Smith, "Disabling the Lie: Prayers of Truth and Transformation," in Eiesland and Saliers, Human Disability, 293.

${ }^{10}$ Matt 8:1-4, 16-17, 28-34; 9:27, 18-26, 27-31, 32-34; 11:5-6; 12:10-14, 15, 22-28; 14:34-36; 15:21$28,29-30 ; 17: 15-19 ; 20: 29-34,21: 14$ (NRSV). The biblical language is less than sensitive, and reflective of the times.

${ }^{11}$ United States Conference of Catholic Bishops, Pastoral Statement of U.S. Catholic Bishops on Persons with Disabilities (Washington, DC: USCCB, 1988).

12 Ibid.,1.

13 Ibid., 2.

${ }^{14}$ Ibid., 3.

${ }^{15}$ Ibid., 3-4.

${ }^{16}$ Ibid., 4.

${ }^{17}$ Ibid., 6.

${ }^{18}$ Holland, Jonathon, Gilger, Patrick, and Gaunt, Thomas P., Disabilities in Parishes across the United States: How Parishes in the United States Accommodate and Serve People with Disabilities (Washington, DC: CARA, 2016), 1.

${ }^{19}$ Fletcher, Laura, "Ramp It Up: How Parishes Can Increase Accessibility," U.S. Catholic 78, no. 12 (2015): $18-22$, at 19.

${ }^{20}$ Quoted in Fletcher, "Ramp It Up," 21.

${ }^{21}$ Gutiérrez, Gustavo, A Theology of Liberation (Maryknoll, NY: Orbis Books, 1988), 9-10.

${ }^{22}$ Ibid., 171.

${ }^{23}$ For a summation, see Eiesland, Nancy, The Disabled God: Toward a Liberatory Theology of Disability (Nashville: Abingdon Press, 1994), chap. 3, "The Body Politics," 49-67.

${ }^{24}$ Ross, Susan A., Anthropology: Seeking Light and Beauty (Collegeville, MN: Liturgical Press, 2012), 9294 (hereafter Light and Beauty).

${ }^{25}$ Eiesland, The Disabled God, 67.

${ }^{26}$ For an opposing viewpoint, see Reinders, Hans S., Receiving the Gift of Friendship: Profound Disability, Theological Anthropology, and Ethics (Grand Rapids, MI: Eerdmans. 2008), esp. chap. 4, pp. 123-50. 
${ }^{27}$ Eiesland, The Disabled God, 63.

${ }^{28}$ See Eiesland and Saliers, Human Disability and the Service of God.

${ }^{29}$ While I have no expertise in canon law, in terms of ordination, it appears to be more a case of prevailing expectations rather than canon law. According to the Vatican website, men are not expressly banned from the Roman Catholic priesthood because of any specifically named disability except for "amentia or other psychic illnesses," which could have a broad application (canon 1041). However, they are impeded by having unnamed "irregularities" for which they can be given a dispensation only by the Holy See, or in some cases, local bishops. Canon 1051 states that "there is to be a testimonial of . . . a properly executed inquiry about his state of physical and psychic health." Again, it appears that the hierarchy has vast discretion. http://www.vatican.va/archive/ENG1104/ INDEX.HTM.

${ }^{30}$ Holland, Gilger, and Gaunt, "Disabilities in Parishes," 5.

${ }^{31}$ Don E. Saliers, "Toward a Spirituality of Inclusiveness," in Eiesland and Saliers, Human Disability, 1931 , at 20.

32 DeVries, "Creation, Handicappism, and the Community of Differing Abilities."

${ }^{33}$ Goffman, Erving, Stigma: Notes on the Management of Spoiled Identity (New York: Simon \& Schuster, 1963); quoted in Sarah J. Melcher. "Visualizing the Perfect Cult: The Priestly Rationale for Exclusion," in Eiesland and Saliers, Human Disability, 57-58. I do not accept all of Goffman's theory, but find it useful to address stigma. There are many critics of aspects of Goffman's theory. For one example, see Eiesland, The Disabled God, 58-61.

${ }^{34}$ DeVries, "Creation, Handicappism," 127.

${ }^{35}$ Ibid., 131 (emphasis in the original).

${ }^{36}$ Copeland, M. Shawn, Enfleshing Freedom: Body, Race, and Being (Minneapolis: Fortress Press, 2010), 2.

${ }^{37}$ Ibid.

${ }^{38}$ Womanist theologian Monica Coleman explores the intersectionality between racism, sexism, and able-ism, based on her authentic, lived experience and her faith journey in Bipolar Faith: A Black Woman's Journey with Depression and Faith (Minneapolis: Fortress Press, 2016).

${ }^{39}$ Massingale, Bryan N., "The Systematic Erasure of the Black/Dark-Skinned Body in Catholic Ethics," in Catholic Theological Ethics Past, Present, and Future: The Trento Conference, ed. Keenan, James F. (Maryknoll, NY: Orbis Books, 2011), 116 (emphasis in the original).

${ }^{40}$ Ellison, Invisible Man, 6.

${ }^{41}$ Ross, Light and Beauty, xii. 
${ }^{42}$ See Reinders, Gift of Friendship; also Haslam, Molly C., A Constructive Theology of Intellectual Disability: Human Being as Mutuality and Response (New York: Fordham University Press, 2012). OpenURL query I Google Scholar Haslam's definition of being human isn't located in capacities for rationality or choice: "Rather, drawing upon the conception of imago Dei in Genesis 1, as well as Martin Buber's I and Thou, I argue that our humanity is located in relationships of mutual responsiveness with the Thou we encounter.... To conceive human being in terms of relationality versus capacity offers a conception of the human that is no longer discriminatory of individuals as participating fully in the category 'human,' as participants in these relationships of mutual responsiveness" (15). Additionally, important theological work in terms of expanding our idea of who makes up the Body of Christ, and how people should be welcomed, has been done by others, including Reynolds, Thomas E., Vulnerable Communion: A Theology of Disability and Hospitality (Grand Rapids, MI: Brazos Press, 2008) and Yong, Amos, Theology and Down Syndrome: Reimagining Disability in Late Modernity (Waco, TX: Baylor University Press, 2007). While their work is valuable in many ways, I have not engaged these authors because Reynolds' concept of "response-ability" relies too much on self-agency for my arguments here, and Yong's strong connections between the dignity of the individual and of the caregiver are not particularly suited to my thesis.

${ }^{43}$ Reinders, Gift of Friendship, 1-2.

${ }^{44}$ Ibid., 137.

${ }^{45}$ Ross, Light and Beauty, 70.

${ }^{46}$ This category of disabilities has numerous definitions that are somewhat in flux. My definition of persons with "profound" disabilities applies to those individuals who, because of severe and/or multiple physically and/or psychologically handicapping conditions, have difficulty communicating their needs to others and are unable to meet their basic needs themselves.

${ }^{47}$ Iozzio, Mary Jo, "Thinking about Disabilities with Justice, Liberation, and Mercy," Horizons 36, no. 1 (2009): 32-49. lozzio challenges our ideas about what ability and disability mean, what relationships mean to people with disabilities, and even the assumption that we know what they mean in light of gospel teaching.

${ }^{48}$ Farley, Margaret, Compassionate Respect: A Feminist Approach to Medical Ethics and Other Questions (Mahwah, NJ: Paulist Press, 2002). Through feminist theology, Farley refutes the idea that independence is what is most desired by people with disabilities, and that independence is the greatest good we can work toward with them.

${ }^{49}$ Reinders, Gift of Friendship, 142.

${ }^{50}$ lbid., 150.

${ }^{51}$ Ross, Light and Beauty, xi.

${ }^{52}$ E.g., Daniel Goleman, "The Experience of Touch: Research Points to a Critical Role," New York Times, February 2, 1988. 
${ }^{53}$ According to the 2010 US Census (https://www.census.gov/2010census/), 2.1 percent of the population between the ages of fifteen and sixty-five needed help with the self-care activities of daily living, and that number jumps significantly with age.

${ }^{54}$ Saliers, "Towards a Spirituality of Inclusiveness," 21.

${ }^{55}$ Ibid., 22.

${ }^{56}$ Ibid., 23.

${ }^{57}$ Ibid., 29.

${ }^{58}$ Copeland, Enfleshing Freedom, 126-27 (emphasis in the original).

${ }^{59}$ These thoughts are gathered from throughout Copeland's book Enfleshing Freedom, esp. chaps. 3 and 4, 55-106.

${ }^{60}$ Copeland, Enfleshing Freedom, 84. Similarly, Dussel, Enrique, in Beyond Philosophy: Ethics, History, Marxism, and Theology (New York: Rowman and Littlefield, 2003), says that there can be no epiphany, or recognition of Christ, except through "the other" (98-99).

${ }^{61}$ Copeland, Enfleshing Freedom, 60.

62 La Pierre, Dominique, City of Joy (Garden City, NY: Doubleday, 1985), 61. The book is considered fiction because of re-created conversations and some changed names, but according to the author and others, it is largely nonfiction.

${ }^{63}$ La Pierre, City of Joy, 86.

${ }^{64}$ Christy Brown, My Left Foot (London: Minerva/Reed, 1954/1996), 10-11.

65 Ibid., 102.

${ }^{66}$ Ibid., 154.

${ }^{67}$ Ellison, Invisible Man, 338-39 (emphasis in the original).

${ }^{68}$ E.g., Colleen C. Grant, "Reinterpreting the Healing Narratives," in Eiesland and Salier, Human Disability, 72-87.

${ }^{69}$ I thank the anonymous reviewer who provided the very helpful phrase "able-bodied privilege."

${ }^{70}$ Sobrino, Jon, The Principle of Mercy: Taking the Crucified People from the Cross (Maryknoll, NY: Orbis Books, 1994). 
${ }^{71}$ For a fuller explanation of L'Arche, see Vanier's, Jean An Ark for the Poor: The Story of L'Arche (New York: Crossroads, 1995), and Henri Nouwen's books, including Adam, God's Beloved (Maryknoll, NY: Orbis Books, 1997).

${ }^{72}$ Nouwen, Henri, Reaching Out: The Three Movements of the Spiritual Life (Garden City, NY: Doubleday, 1975); quoted in Jan B. Robitscher, "Through Glasses Darkly: Discovering a Liturgical Place," in Eiesland and Saliers, Human Disability, 148.

${ }^{73}$ Episcopal Diocese of Michigan, "Accessibility Survey," Disability Awareness, http://www.daedomi.org/con-survey.html; NCPD (National Catholic Partnership on Disabilities), "Parish Accessibility Surveys," NCPD, http://www.ncpd.org/accessible-design/surveys; United Methodist Church, "Disability Ministries Audit," DisAbility Ministries Committee of the United Methodist Church, http://www.umdisabilityministries.org/resource.html.

${ }^{74}$ In ST III, q. 80 Aquinas gives us guidelines on including people who would have been called feebleminded, and urges priests to err on the side of inclusion. Additionally, Aquinas has been interpreted broadly to be more inclusive than exclusive as regards including persons with disabilities in the life of the church. See Carlson, Mary, "Aquinas on Inclusion: Using the Good Doctor and Catholic Social Teaching to Build a Moral Case for Inclusion in Catholic Schools for Children with Special Needs," Journal of Catholic Education 18, no. 1 (2014), http://dx.doi.org/10.15365/joce.1801042014.

${ }^{75}$ For more information, see SPRED, Special Religious Development, Archdiocese of Chicago, www.spred-chicago.org.

${ }^{76}$ Copeland, Enfleshing Freedom, 127.

77 Pope Paul VI, Apostolic Letter, Octogesima Adveniens, May 14, 1971, §48, http://w2.vatican.va/content/paul-vi/en/apost letters/documents/hf pvi apl 19710514 octogesima-adveniens.html.

${ }^{78}$ In an email conversation with Janet McKenzie on September 28, 2016, the artist confirmed that the child upon whom she modeled Jesus had been born prematurely, which caused developmental delays. For examples of McKenzie's inclusive work, see Perry, Susan, ed., Holiness and the Feminine Spirit: The Art of Janet McKenzie (Maryknoll, NY: Orbis Books, 2009).

${ }^{79}$ Robitscher, "Through Glasses Darkly," 144-45. 